\title{
Needy Guests, Reluctant Hosts? Refugee Women from the Former Yugoslavia in Hungary
}

\author{
Éva V. Huseby-Darvas
}

In the late spring of 1992 I conducted preliminary research in Hungary. ${ }^{1}$ On the one hand, I was interested in how the refugee experience affects women's perception of their ethnic and gender identities, cultural heritage, and social, economic, and familial roles. On the other hand, I was eager to examine the host population's reactions to the refugee situation and some of the perceptions of self and others amid what was rapidly becoming a refugee crisis. ${ }^{2}$ I conducted most of my fieldwork on refugees at the refugee camp at Nagyatád and Bicske.

Wanting to go home was the leitmotif of stories I heard from the great majority of the people from former Yugoslavia. They were representative of their group in this respect, as illustrated by the fact that over 95 percent of the refugees asked only for temporary asylum. Of course, this is not unusual; as Sylvana Foa, spokesperson for Sadako Ogata, the United Nations High Commissioner for Refugees (UNHCR) said, "99 percent of the refugees in the world want to go home. People don't give up their culture, home, friends and belongings lightly." 3 Not surprisingly, the refugees who did not want to go back home but asked for permanent asylum in Hungary or wanted to emigrate belonged to a double minority group, for instance, families of Hungarian Gypsies from northern Yugoslavia did not want to return. As I was told by a Rom in his early fifties, the memory of over 200,000 Gypsies who were put into Croatian-operated concentration camps and murdered during World War II was still "burning in our hearts-we were afraid."

At the time of my fieldwork, it was estimated that only about 15 percent of

Éva Huseby-Darvas is associate researcher at the Center for Russian and Eastern European Studies, University of Michigan. the Croatians and ethnic Hungarians actually stayed in camps. Those who had friends or relatives in Hungary stayed with them, and the ones who had money were paying guests in pensions, hotels and private homes. Many of the refugees were simply not registered. It is therefore very difficult to establish the exact number of refugees in Hungary. In March 1992 just over 50,000 were registered refugees from Yugoslavia, 40,000 from Romania, and several thousand from elsewhere. In addition, according to Istvan Morvay's report a month later, ${ }^{4}$ there were an estimated 25,000 illegal (unregistered) refugees from Romania, 50,000 from the former Yugoslavia, and about 100,000 from Asia, Africa and elsewhere. An influx like this in Hungary, a country with a population of 10.5 million, would be compatible to a sudden flood of over 400,000 refugees to Canada or four million newcomers to the United States. Of course, these comparisons are neither fair nor realistic. Hungary is a much smaller, more densely populated and considerably poorer country than either Canada or the United States. Hungarian society is still reeling from the regime change, struggling politically, economically and culturally amid an identity crisis.

By July 1992 there were serious concerns that the entire refugee-supporting infrastructure would soon crumble in Hungary. The concerns were well founded: only 20 percent of the costs to house, clothe, feed and care for refugees came from the United Nations and other Western sources. The remaining 80 percent was either advanced by Hungary or covered by Hungarian sources without the hope of reimbursement. ${ }^{5}$

As elsewhere in the contemporary refugee population, which, according to UNHCR, is an estimated twenty million worldwide, about 65 to 70 percent of the refugees in the camps from the former
Yugoslavia were women and their young dependants. ${ }^{6}$ My informants told me that some men were killed before the women left home. In other cases the husbands, fathers and sons left with their families, then returned to fight. In still other cases, men encouraged the women to leave with the children, while they stayed home to fight. In those cases where the young or middle-aged men came with their families and stayed on in the camps, the most frequently and heatedly discussed topic was returning to their home towns, so they can be counted there in what already seemed to be an escalating crisis. Thus, in late May 1992 most of the population in the camp at Nagyatád in southwestern Hungary was composed of women and children. The average age appeared to be thirty-two, but this was due to the over-representation of seniors (mostly women) and children. While most professions were represented, most adults were agrarian workers, peasants or commuting worker-peasants living in small towns and villages before they were forced to flee their homes. The ethnic composition of the refugees was as follows. In November 199160 to 65 percent of them were Croatian and 25 to 30 percent were Hungarian. On June 6, 1992, as a result of "ethnic cleansing," 2,000 Bosnian refugees arrived in the camp, and on July 9 , 1,273 more Bosnians were returned by train from Viennabecause Austria, along with the rest of western Europe, refused to take in any more refugees. As a result, the ethnic composition in the camp has changed so that approximately 60 percent of the refugee population was Croatian, 30 percent Hungarian and 8 percent Bosnian.

Before August 1991, the refugee camp at Nagyatád was a major Hungarian army post with the maximum capacity for 3,000 men. Thus, the camp has all the characteristics of socialist architec- 
ture and workmanship. The bathrooms were obviously designed for men only; there are no locks on the doors, for instance, and there are many more urinals than lavatories. The barracks are multistoried, with huge rooms that can accommodate up to fifty soldiers. For the refugee women, most of whom were used to living in individual village houses surrounded by household plots and orchards, forests and vineyards, livingin the camp was very difficult, but not necessarily because of these drawbacks. As Magda, an ethnic Hungarian woman in her fifties from a small town just across the border, told me, "These Hungarians don't really know how to work, and they don't like to work either. But the other day I saw this woman work in her field. It just broke my heart. Who is working my land? They give us everything here. I would be lying if I complained about anything. They are kind to us, feed us, the kids are in school, they set up everything right here for us, but someday I'll just go crazy. I had my own orchard. I miss it, I miss working on the land. Here we are just pacing, walking up and down several times a day, eating, sleeping a bit and talking. We are talking so much."

A number of studies, ${ }^{7}$ including those by my colleagues, my own research on immigrant and refugee women in North America for over a decade, as well as my personal experience as a refugee, show that refugee women's experiences are tremendously complex. It is commonplace, for instance, that numerous aspects of the refugee experience have both positive and negative aspects, many gains and losses for an individual. While refugee women often appear to gain a considerable amount of independence, at the same time they are frequently very vulnerable and considerably exploited. Clearly, women are greatly influenced by the radical changes in family structure, values, expectations and changes that are direct results of the refugee experience. Family violence is more frequent and much more visible in the campenvironment than it was before. As these

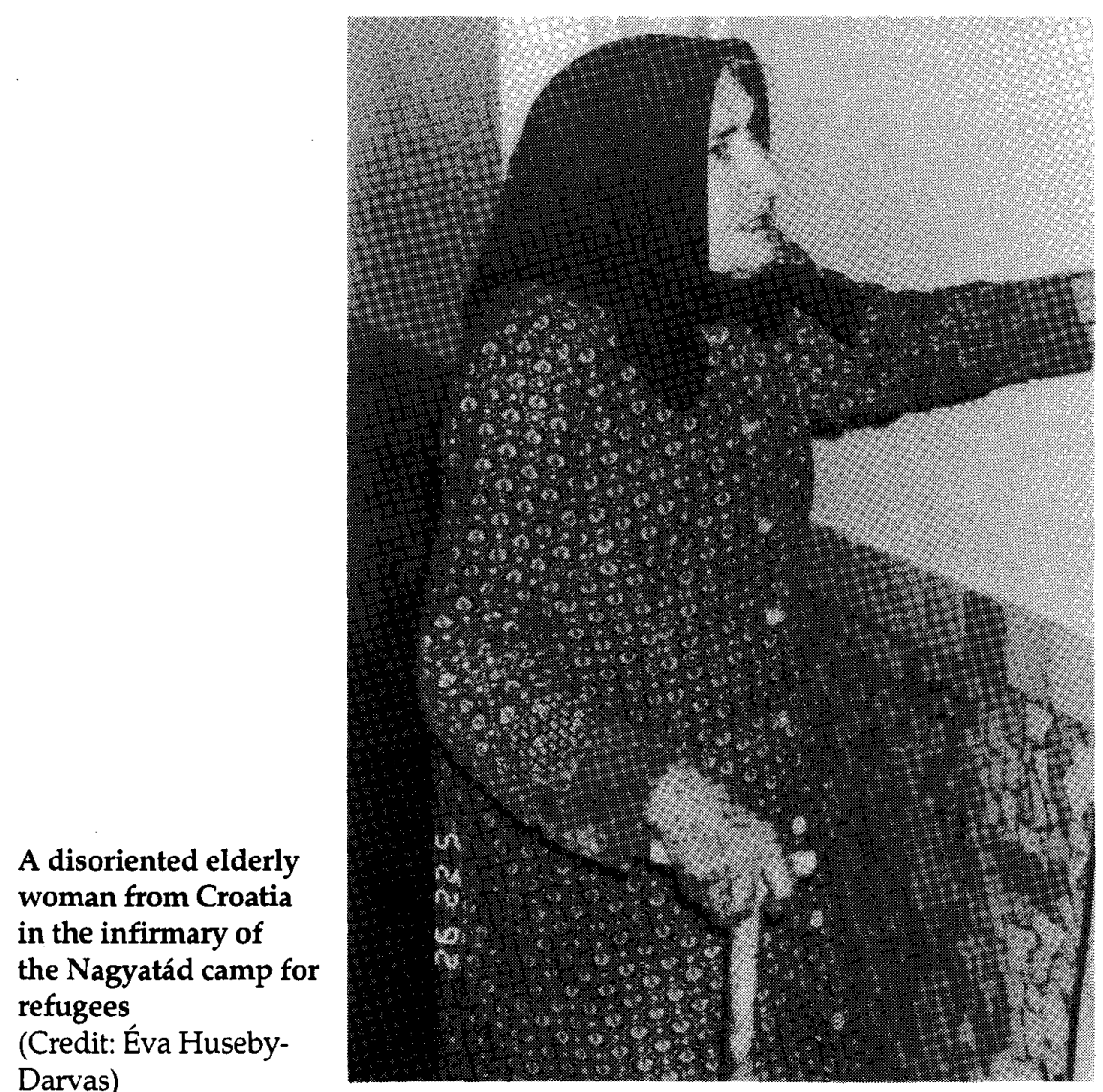

studies show, separations become more frequent and divorce rates often increase. These were obvious in the camp at Nagyatád.

The physical and psychological effects from the loss of a home, but particularly the loss of traditional support systems of networks of female kin, as well as those within neighbourhood and village communities, were painfully evident. Grieving and post-traumatic stress disorder were common among the refugee women. Particularly (but not only) the women in the infirmary were decidedly confused about where they were, why they were there and where they were in relation to their homes. The uncertainties about their own plight and future appeared to be overshadowed by the constant worries about the whereabouts of their sons, husbands and brothers, and about the younger children's activities in the camp. Even among those whose menfolk were not in the camp, domestic violence was present and becoming more and more frequent. One widow, whowas born in 1930 and whose son, daughter-in-law and grandchildren were all living in the camp for over five months, complained of increasing physical abuse from her son and her grandchildren, and of daily verbal abuse by her daughter-in-law, stating over and over. again, as if excusing them, "My son was so good to us before the war. Their nerves suffered from having to leave our home. There is nothing to do for us here. He just sits and thinks all day about whether to go back home or stay here. We were always busy at home. What is there to do here? The kids could be busy with school and play here in the camp, but what about the rest of us?"

It was obvious that there is a dire need for small-scale ethnographic studies that would give the women's views on their new circumstances and serve as a much needed testimony for them. From these accounts we could easily and more precisely examine what happens to family patterns, gender roles and women's status during the refugee experience.

Confusion and frustration, boredom and alienation were frequently expressed. Even those ethnic Hungarian women who were intimately familiar 
with the area of southwestern Hungary because for decades they regularly crossed the border to shop and at times to sell at the markets and fairs in this region, and who consequently built various social networks there, were alienated and often confused. ${ }^{8}$

While there were numerous signs that the traumatic experience contributed to family and community disruption, there were extraordinary and repeated emphases on the structure, continuity and significance of kinship, fictive kinship and just recently developed solidarity. For instance, terms of kinship, fictive kinship and neighbourhood were extended beyond the traditionally used spheres and often shifted across boundaries of the ethnic groups. The way refugee women dressed up in their best clothes and promenaded on the streets of the camps, or decorated rooms in the barracks, or the way in which older
In the Nagyatád camp on looms on loan from Hungarian folk museums, using wool yarn donated by a Maltese religious order, older women from a nearby village were weaving the traditional patterns of their community into pillowcases, tablecloths and rugs. Like so many of the other women in the camps, they told their stories too: "Our village is no more. Our houses are burned down, the church steeple was shelled and fell. But we still want to go home.... We will not have any furniture left to put these [woven items] on, but we will manage if we could only go home."

Until the beginning of the ethnic cleansing, much of the asylum-seeking migration from the former Yugoslavia was understood to be-certainly by those asking for asylum-temporary. In some cases, the entire process of escaping was initially interpreted lightly. For example, I was told that some of the

\section{The escalation of war and the accompanying insanity of ethnic cleansing in the former Yugoslavia brought on the very worst refugee crisis in Europe since World War II.}

women sat outside the barracks after sunset, were all attempts to create a community away from home. Thus, it seemed that, despite the extreme trauma of the refugee experience, a number of women were well adjusted and tried to reestablish meaningful lives in the new environment of the camp. It was painfully evident that telling and retelling the stories of how, why, when and with whom they fled their homes and what they left behind was immensely important to the women. Their stories were like a reenactment of a ceremonial or a confirmation of ritual among other political refugees. They too had a great desire to talk, to tell each other and the interested outsider the circumstances of how, when, why and with whom they had escaped. Some tell their stories over and over again to one another. I had no difficulty eliciting the stories from these women. Rather, while some of the men were openly suspicious, none of the women seemed distrustful or hesitant.
Croatians and ethnic Hungarians took their vacation times, left their homes in Osijek or a nearby town or village to travel with their families to spend what they initially believed would be a few weeks in Hungary. As one man told me, "At first we were convinced that the madness cannot last much longer, surely it will be over soon. I no longer know what to believe."

The escalation of war and the accompanying insanity of ethnic cleansing in the former Yugoslavia brought on the very worst refugee crisis in Europe since World War II. Part of this crisis was that by mid-July 1992 the West was not only reluctant to accept refugees, but in fact closed its gates, and in Hungary there were very serious concerns that the entire refugee-maintaining infrastructure would crumble. Incidentally, this was at precisely the same time when the UNHCR declared that Hungary's actions in the refugee crisis was most valued and that Hungary was showing an outstanding humanitarian example to the world. On July 20 the camp in Nagyatád was filled beyond its capacity: in addition to the barracks, numerous tents were erected all over the camp. It was closed to all newcomers, except for cases of family reunification or for old or sick refugees or for those with children.

The second question I asked in my research was what this great flood of refugees means to Hungarians. Particularly, how does it affect their perception of self, their ideas about Hungary's place in the world, in the so-called New World Order? Not only was I listening and asking questions in Hungary, but I have also been doing a version of what anthropologists call studying cultures from a distance. In trying to comprehend the reactions of the host population to the refugee crisis in that country, I deliberately chose to look at a number of different sources for this information: ongoing telephone and electronic mail communication with my colleagues and informants, reading Hungarian and other newspapers, supplemented by daily reports of Radio Free Europe.

Reading the studies of my colleagues, ${ }^{9}$ looking at results of polls and listening to informants talking about the refugee question in Hungary was not merely fascinating and informative but also contradictory and confusing. Endre Sik discusses the problem from the perspective of public opinion, a deteriorating economic situation, and the formation of stereotypes that are based on half-truths amid a dire shortage of "political and other institutionalized mechanisms to moderate the collective mood of the population," and concludes that "among the population inevitably, refugee related prejudice is on the rise." ${ }^{\prime 10}$ In the same vein, Zavec ${ }^{11}$ projects that in the future-when there will be fewer ethnic Hungarians among the refugeesserious problems are likely to result from the settlement and accommodation, even temporary asylum of refugees.

While there are perhaps as many different responses to the refugee situation in Hungary as there are respondents, I will discuss two types and a few subtypes of reactions. First, I found a humanitarian response. Although in 
October 1991 there was concern in public opinion polls that the country will become exhausted in supporting the refugees, there was and still is pride in many Hungarians for taking the refugees in because it is the "humane thing to do." There is also anger towards the "proud, wealthy and compassionless West" for turning away trainloads and boatloads of refugees. At the same time, as a prominent intellectual wrote in reaction to the disclosure that Jacques Attali, a representative of the International Monetary Fund and UNHCR, once again promised but did not send enough money for the maintenance of the refugees, "the West is turning away from us and from our needs, so we are, once more, behind the back of God and the West."

A more extreme version of this response is one that stresses the victimization of Hungary and Hungarians. On the one hand, what are emphasized are the goodness, helpfulness and humanitarian ways of Hungarians. On the other hand, there is also a concern best expressed by the following quote: "Once again we are being put upon: the West is, once again taking advantage of us, once again we are the protectors of European humanitarian values, but we are once again pushed out on the semiperiphery between the Balkans and the European community." Reports are written and published about the average, simple-hearted, hard-working man of the street, people who are disturbed that "again Hungary, this little island of peace, is taken advantage of by the West and used as a veguar" (final fortress) in a Christian civilized Europe. ${ }^{12}$

Europe prides itself on being affluent and civilized while turning away from helping the unfortunate, but Hungary is still helping-in spite of the tremendous economic burden that the great flow of refugees means to a country that is already struggling with unemployment and inflation, while experiencing political and socio-economic hardships. ${ }^{13}$

Then there is another type of reaction that is negative and hostile. Its proponents construct and pass on different types of stereotypes than those discussed in the previous passages. It is best illustrated by what some of my informants told me. For example, a forty-twoyear-old clerical worker in Budapest said indignantly: "Demszky [the mayor of Budapest] wanted all these foreigners to come here. Don't ask me why, I don't know. So now all the Gypsies, Romanians, Yugoslavs and other foreigners are all over the place. To top it off, Demszky urges us to give these foreigners clothes, blankets and food, but from what? We hardly have enough for ourselves anymore. Listen, today there are people in Hungary who are starving. There are the decent people on fixed incomes, on retirement and disability pensions. There are people who go to the streets and chant in processions of tens of thousands that 'we are hungry, we are cold'. So why should we give anything to these foreigners? They come here, and then decent Hungarian folks are fired from their jobs so the foreigners can be hired because they are willing to work for a quarter of what the decent Hungarians were paid. Where is the justice in this? Tell me."
A few days later, the same person said to me, "even when I turn on the tap, instead of water, news about refugees pours out. Enough already! Who the hell cares?"

There are many people who blame not only the economic problems on the refugees but also the explosive growth in street crime, drug and prostitution rings. I found this kind of scapegoating strikingly similar to that elsewhere throughout western, as well as eastern and east central Europe in the late spring and early summer of $1992 .^{14}$

Another informant, a commuting skilled worker in his late thirties, told me, "Now here is this mob. Strangers, you know-rabble from only God knows where. Not that long ago they killed a decent Hungarian kid nearby. No wonder everyone is against them. Everybody curses them in the factory too. The government set up a proper camp for the Yugok [Yugoslavs]. So I told the wife, 'Soon they will be eating better than we are eating'. Imagine-meat every day, in

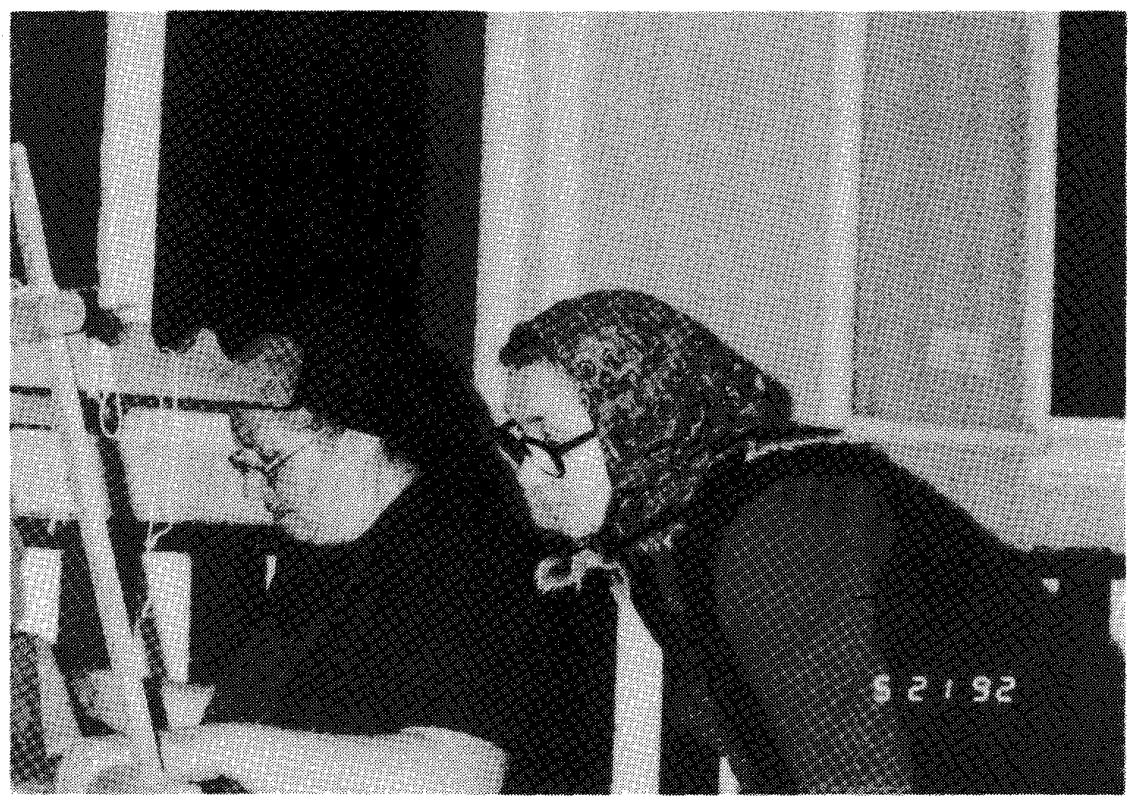

In the Nagyatád camp, refugee women from the former Yugoslavia are weaving with wool sent by the Maltese Order on looms lent by the Hungarian Ethnographic Museum. (Credit: Robert Darvas) 
these hard times. So what did this foreign mob do? They rebelled and beat up the decent, hard-working Hungarian guards. Let the barbarians in and this is what you get for thanks."

Here, clearly the identities of "us" the good, decent, helpful, hard-working, humane Hungarians are juxtaposed to those of the "other" - the evil, barbarous, foreign rabble whose lot by some weird quirk of fate has destined them to become privileged people at the expense of their host population.

Similar to these reactions but more extreme is the reaction of the far right. Hungary's skinheads-who proudly declare themselves to be "number one in eastern Europe," and whose leaders carefully cultivate their association with German, Austrian and other Western skinhead organizations-generally focus their frequent verbal and written attacks on foreigners, particularly on students of color from the Third World who study at various Hungarian universities and colleges, and on Hungary's Jewish and Gypsy populations that are estimated to be 80,000 to 100,000 and 600,000 to 800,000 , respectively, depending on who is doing the counting and for what purpose. The slogans of the far right, "Hungary for the Hungarians," and "Arabs, go home" are central to their ideology, ${ }^{15}$ while "Foreigners, out!" is the more recent cry of battle of other organizations of similar ilk, like the Hungarian neo-fascists. ${ }^{16}$

It is crucial to emphasize, however, that even though these and similar xenophobic voices have been clearly heard since 1989 in postsocialist Hungary as much as they have been in other parts of Europe, ${ }^{17}$ in Hungary the growing number and increasing visibility of refugees have not elicited the kind of rampant xenophobia characterized by blind, pogrom-like eruptions against foreigners as it did, for instance, in Germany or Italy. Still, there is considerable official concern, as evidenced by the A pril 1992 statement of Hungarian Prime Minister Jozsef Antall: "It is clearly the case that there is direct correlation between acute economic problems, unemployment and the fall in the standard of living, and growing xenophobia. However, our government tries everything in its power to curb xenophobia in the country." 18

Indeed, in Hungary, as elsewhere in the former Soviet bloc, these are critical times. The transition of the economy from central control to market orientation is a very difficult one. The number of unemployed, particularly in certain counties has grown rapidly to an estimated 17 percent by late 1992. Among the various attempts to fill the ideological vacuum is the effort of a still relatively small, but rabidly fanatical and loudly belligerent group. This group, using the rhetoric and symbols from the very darkest period of recent Hungarian history, incite xenophobia and foster similar hatreds and fears among a growing number of followers. With Hungary beyond the saturation point in playing reluctant host to an increasingly needy and growing refugee population, ${ }^{19}$ the imbalance is becoming critical between the real, tremendous economic and social problems and the ideal self-image of Hungarians as the noble, helpful, nurturing folks who are helping the downtrodden while the rest of the world is turning its back.

Yet sadly it looks as if it is still true what Jane Kramer ${ }^{20}$ wrote-that in the West "the panic about immigrants from East Europe has been mainly a financial panic." It is time for it to be a thoroughly informed and carefully considered humanitarian concern. Somewhere a reporter commented that an event is only attractive for the media if it is dynamic, photogenic and if it happens in a narrow and well-defined space. The refugee crisis is none of these and rapidly getting less photogenic and much more widely scattered.

So the question remains: what is the West-Canada, the United States, the European Community and Australia going to do with the current refugee crisis in southeastern Europe? In addition to more funds, more clothes, diapers, blankets, toys, sanitary napkins, toilet paper, decent shoes and boots that are desperately needed now, there is dire need for more attention, more understanding and, most importantly, a more flexible, open and reasonable immigration policy.

\section{NOTES}

1. I am most appreciative of the help of my colleagues, EndreSikand Ákos Róna-Tas, without whose kind help my research on which this work is based would have not been possible. János Einvachter, director of the refugee camps at Nagyatád and Bicske, was also very helpful, cooperative and most hospitable. For securing research permits with the greatest speed and ease and the least amount of bureaucracy that I have ever experienced in Hungary in more than a decade of research, Dr. Ágnes Ambrus, Department of Refugee Affairs, Hungarian Ministry of the Interior, deserves recognition and many thanks.

2. After the exodus of Germans from East Germany via Hungary to West Germany in 1989, and the massive wave of refugees from Romania, the people escaping from the former Yugoslavia actually composed the third major wave of refugees in about as many years in Hungary.

3. Cited both by Susan Martin Forbes, Refugee Women (London: Zed, 1992), and by Felicity Barringer, "Repatriation Is the Trend for Refugees Worldwide," The New York Times (November 17, 1991).

4. Hírmondó (April 12, 1992).

5. Hirmondó (July 20, 1992).

6. This was not the case with the refugee population in Hungary from Romania a few years earlier. Data on the refugees in Hungary from the former Yugoslavia cited here by the kind courtesy of the Nagyatád camp's staff.

7. See, for example, references cited by Abadan-Unat (1977), Martin Forbes (1992), Marokvasic (1981), Gozdziak (1990), Sik (n.d.), Markowitz (1986, 1988), Whiteford (1978), as well as the studies in the special issue of Anthropological Quarterly 1976 Vol. 76 on women and migration.

8. On the importance of premigration economic and social contacts, see Sik (n.d.).

9. Particularly those of Endre Sik (1992, 59-74) and Tibor Zavecz (1992, 49-58).

10. Sik (1992, 59-74; and also 1991, 366-78).

11. Zavecz $(1992,57)$.

12. Keri (1992).

13. Verebes (1992).

14. See, for example, Jan Rydl and Sabina Slonkova, "A Russian, Ukrainian, Uzbek and Chechen Mafia in Czechoslovakia: A Report," Prague News, No. 11, May 29-June 12:3. Of course, amid all this 
demographic transformation in Europe, ethnic and national identities are newly fabricated and continuously rearticulated, as Anderson (1992), Lutz (1991) and Liebkind (1989) discuss.

15. Gerloczy (1991).

16. Hajba $(1992,1,4)$.

17. Riding (1991), Kinzer (1991, 1992).

18. Cited in Hirmondó (April 1, 1992).

19. Here I am dealing with the refugee situation in Hungary. At the same time, I am certainly aware that other countries in the region, particularly Slovenia and Croatia, are also struggling with a tremendous refugee crisis.

20. Kramer (1991).

\section{REFERENCES}

Abadan-Unat, N. 1977. "Implications of Migration on the Emancipation and Pseudoemancipation of Turkish Women." In International Migration Review 6, no. 1:3157.

Anderson, Benedict. 1992. "The New World Disorder." In New Left Review 193 (MayJune 1992): 3-15.

Anthropological Quarterly. 1976. Special Edition on Women and Migration 49, no. 1 (January).

Barringer, Felicity. 1991. "Repatriation Is the Trend for Refugees Worldwide." In The New York Times (November 17).

Gerloczy, Ferenc. 1991. "Magyar borfejuek" ["Hungarian Skinheads"]. In Heti Világgazdaság (November 30).

Gozdziak, Elzbieta. 1990. “Changing Role of Refugee Women." Unpublished.

Hajba, Ferenc. 1992. "Szabadlábon vannakaz ujfasisztaák" ["Hungarian Neo-fascists Are Freed"] and "A Gyanusított nyilatkozik" ["The Suspect Gives a Statement"]. In Népszabadság (January 21): 1, 4.

Kéri, Tamás. 1992. "Menekulhetnek-e a menekulok?" ["Can the Refugees Escape?"] In Népszava (July 16).

Kinzer, Steven. 1991. "A Wave of Attacks on Foreigners Stirs Shock in Germany." In New York Times (October 1): 1, 6.

1992. "Munich Journal: Last Straw? Refugees at Fest's Field." In New York Times (March 19):A4.

Kramer, Jane. 1991. "Letter from Europe." In The New Yorker (July 29): 63-73.

Liebkind, Karmela, ed. 1989. New Identities in Europe. Aldershot: Gower Publishing.
Lutz, Wolfgang. 1991. Future Demographic Trends in Europe and North America: What Can We Assume Today? New York: Academic Press.

Markowitz, Fran. 1988. "Rituals as Keys to Soviet Immigrant Jewish Identity." In Between Two Worlds: Ethnographic Essays on American Jewry, edited by Jack Kugelmas. Ithaca: Cornell University Press.

Martin Forbes, Susan. 1992. Refugee Women. London: Zed Books.

Morokvasic, M. 1981. "The Invisible Ones: A Double Role of Women in Current European Migration." In Strangers in the World, edited by L. Eitlinger and D. Schwartz. Bern, Stuttgart and Vienna: Hans Hubert Publishers.

"Refugees Trying Luck, Patience in Poland." In Sarasota Herald Tribune (December 26, 1990): 7A.

Riding, Alan. 1991. "Europe's Growing Debate over Whom to Let Inside." In New York Times (December 1): 2 .

Rydl, Jan, and Sabina Slonkova. 1992. "A Russian, Ukrainian, Uzbek and Chechen Mafia in Czechoslovakia: A Report." In Prague News, no. 11 (May 29-June 12): 3.

Sik, Endre. n.d. "Reconversion in the Course of Migration: Transylvanian Forced Migrants in Hungary."

1992. "Transylvanian Refugees in Hungary and the Emergence of Policy Networks to Cope with the Crisis." In Journal of Refugee Studies 5, no. 1.

1992. "A menekultekkel kapcsolatos eloitéletesseég novekedesenek elkerulhetetlensége" ["The Inevitability of Growing Prejudice Against Refugees"]. In Menekulok, Vádorlok, Szerencsét Próbalok [Refugees, Wanderers, Fortune-Hunters], edited by Endre Sik. Budapest: MTI Politikai Tudományok Intézete Évkonyve.

Verebes, István. 1992. “Én vagyok, mert lehetnék!" ["But For the Grace of God Go I"]. In Mai Nap (July 18).

Whiteford, M.B. 1978. "Women, Migration, and Social Change: A Columbian Case Study." In International Migration Review 12, no. 2:236-47.

Závecz, Tibor. 1992. "Csokkeno Rokonszenv: A Magyar Társadalom itéletei, viselkedései a menekultekkel kapcsolatban" ["Decreasing Sympathy: The RefugeeRelated Opinions and Judgments of Hungarian Society"]. In Menekulok, Vándorlók, Szerenscét Próbalók [Refugees, Wanderers, Fortune-Hunters], edited by Endre Sik. Budapest: MTI Politikai Tudományok Intézete Évkonyve.
Research, Conference and Travel Grants

\section{CENTRE FOR REFUGEE STUDIES York University}

CRS grants are intended to assist and encourage research on "refugee and development" ways of understanding and resolving refugee problems in developing countries.

This includes support for research activities on the following topics:

- Refugee settlement in less developed countries

- Repatriation and development in less developed countries

- Forces affecting refugee generation in less developed countries

- Global changes and policies in sending and receiving countries as well as activities of international agenciesthat will affect refugee generation and development efforts.

Applications are considered twice a year. Completed applications must be received by November 15 and March 15 for funding decisions by January 15 and May 15 respectively.

Forfurther details, please contact:

Helen Gross

Student/Faculty Liaison

Centre for Refugee Studies

Suite 322 , York Lanes

York University

4700 Keele Street

North York, ON

Canada M3IIP3

Tel: (416) 736-5663

Fax (416) 736-5837

E-mail via BITNET, address:

REFUGE@YORKVMI

(C) Éva V. Huseby-Darvas, 1993. This open-access work is licensed under a Creative Commons Attribution-NonCommercial 4.0 International

License, which permits use, reproduction and distribution in any medium for non-commercial purposes, provided the original author(s)

are credited and the original publication in Refuge: Canada's Journal on Refugees is cited. 